\title{
Adenosinetriphosphatase Activity of Squid Myosin*1
}

\author{
Takahide TsuchIYA ${ }^{* 2}$, Noboru YAMADA ${ }^{* 2 * 3}$, Hisayo MoRI ${ }^{* 2}$, \\ and Juichiro J. MATSUMOTO*2
}

(Received August 25, 1977)

\begin{abstract}
Myosin of the obliquely striated mantle muscle of squid, Ommastrephes sloani pacificus, was isolated by the authors' method and its ATPase profiles were studied under various reaction conditions. With $\mathrm{Ca}^{2+}(5 \mathrm{~mm})$ or $\mathrm{Mg}^{2+}(1 \mathrm{~mm})$ present and in $600 \mathrm{mM} \mathrm{KCl}$, the activity-pH curve showed 2 peaks, at $\mathrm{pH} 7.0$ and near $\mathrm{pH} 8.5$, where the activity with $\mathrm{Ca}^{2+}$ was higher than that with $\mathrm{Mg}^{2+}$. The activity -ionic strength curve gave a peak at $0.2 \mathrm{M} \mathrm{KCl}$ with declining slope beyond that concentration. $\mathrm{Ca}^{2+}$ activated the ATPase with a maximum effect at $1-9 \mathrm{~mm}$, while $\mathrm{Mg}^{2+}$ caused a slight activation with a maximum effect at $0.1 \mathrm{~mm}$. The activity was depressed with EDTA for all concentrations between $0.1-1 \mathrm{~mm}$, but in a different manner from the ATPase of skeletal muscle myosins. PCMB did not affected either $\mathrm{Ca}^{\mathrm{2}+}$-ATPase or EDTA-ATPase. These profiles of the squid myosin ATPase were compared with those of the myosin ATPases from other sources. The squid myosin ATPase was found to be very different from the skeletal muscle myosin ATPases and, in some detailed points, distinct from the myosin ATPases from invertebrate and nonmuscular sources.
\end{abstract}

In the authors' program to elucidate the protein constitution of the obliquely striated muscle of squid mantle, isolation and characterization of physico-chemical properties of the myosin have been reported in the previous papers., 2\} For characterizing the properties of myosin in relation to the contractile function of muscle, description of the ATPase activity profiles is necessary. With the ATPase activity of the invertebrate myosins, information is not so abundant as those of the vertebrate myosins due to the presence of paramyosin in the invertebrate muscles which is hardly removed from the myosin preparation and might interfere with the ATPase profile. Works have been reported by RÜEGG ${ }^{33}$ and BÁRÁNY ${ }^{4}$ on Pecten myosin, by De VILlafranca ${ }^{5 /}$ on Limulus myosin, by NISHIDA $^{61}$ and HASHIMoto ${ }^{7,8}$ on Pecten and lobster myosins, by HIGASHI ${ }^{91}$ on abalone myosin, and by YamaGuchi ${ }^{101}$ on Ascaris myosin which has an obliquely striated muscle structure similar to the squid mantle, respectively. With the squid muscle proteins, ATPase activity of actomyosin has been studied by DE VILLAFRANCA and the present authors. ${ }^{121}$

The present paper deals with the characteri- zation of the ATPase activity of the squid myosin isolated intact and almost free of paramyosin by the method reported previously. I!

\section{Materials and Methods}

\section{Material}

Fresh squid, Ommastrephes sloani pacificus, was purchased at the Tokyo Central Wholesale Fish Market.

\section{Squid Myosin}

Myosin was prepared from the squid mantle muscle according to the method developed by the authors. ${ }^{11}$

\section{Carp Myosin}

Myosin was prepared from dorsal lateral muscle of carp, Cyprinus carpio, according to the method reported previously. ${ }^{141}$

\section{Determination of ATPase Activity}

The activity was measured at $25^{\circ} \mathrm{C}$ under the following conditions: Protein, $0.2 \mathrm{mg} / \mathrm{ml} ; \mathrm{KCl}$, 50 or $600 \mathrm{~mm}$; Tris-maleate buffer ( $\mathrm{pH} 7.0$ ), $20 \mathrm{~mm}$;

\footnotetext{
*1 Studies on squid mantle muscle proteins-VI; Read before the Annual Meeting of the Japanese Society of Society of Scientific Fisheries, Tokyo, April 2, 1975. This work was supported by the Grant of Ministry of Education, Science and Culture.

*2 Department of Chemistry, Sophia University, Kioi-cho 7, Chiyoda-ku, Tokyo 102 (土屋隆英・山田 㫧・ 森 寿代・松本雷一郎: 上智大学理工学部).

*3 Present address: Central Research Laboratory, Midorijuji Co., Ltd. Miyakojima-ku, Osaka 534 (ミド リ十字中央研究所).
} 
ATP, $1 \mathrm{~mm}$; either of $\mathrm{MgCl}_{2}(1 \mathrm{~mm}), \mathrm{CaCl}_{2}(5 \mathrm{~mm})$ or EDTA (1 mm). Reaction time, 5 min. The phosphate liberated was determined by FISKE and SUbBarow's method. ${ }^{131}$

Unless otherwise stated the methods used were the same as reported previously. ${ }^{1,2,12,14}$

\section{Results}

ATP splitting in the Function of Reaction Time

ATPase activity was measured at various times of reaction in the presence of either $\mathrm{Ca}^{2+}(5 \mathrm{~mm})$, $\mathrm{Mg}^{2+}(1 \mathrm{mM})$ or EDTA (1 mM) resulting in Fig. 1 . The ATPase was activated markedly with $\mathrm{Ca}^{2+}$, and slightly with $\mathrm{Mg}^{2+}$, while it was depressed by EDTA. These patterns coincided with those of the squid actomyosin ${ }^{12}$ and resembled those of the Pecten myosin. ${ }^{3,4}$

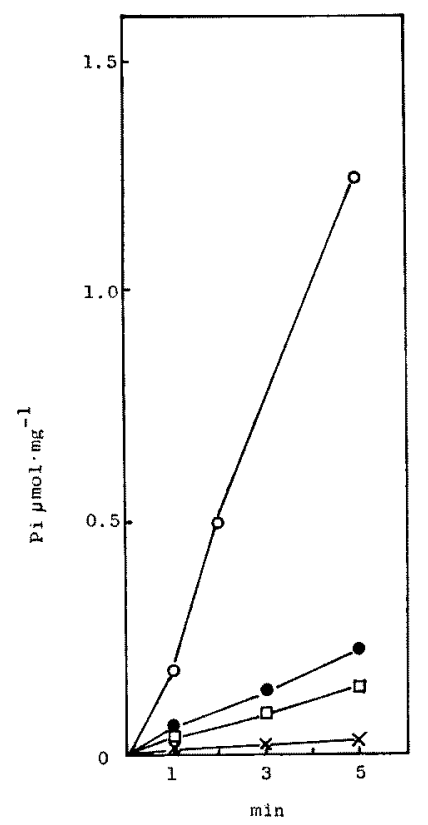

Fig. 1. Effect of $\mathrm{Ca}^{2+}, \mathrm{Mg}^{2+}$ and EDTA on the time course of Pi liberation from ATP by squid myosin ATPase.

Conditions: protein, $0.2 \mathrm{mg} / \mathrm{ml} ; \mathrm{KCl}, 600 \mathrm{~mm}$; Tris maleate buffer ( $\mathrm{pH} 7.0$ ), $20 \mathrm{mM}$; ATP, $1 \mathrm{~mm}$; either of $\mathrm{Ca}^{2+}(5 \mathrm{mM}), \mathrm{Mg}^{2+}(1 \mathrm{mM})$ or EDTA (1 $\mathrm{mm}) . \quad 0-05 \mathrm{~mm} \mathrm{Ca}^{2+}, \times-\times 1 \mathrm{~mm}$ EDTA, $\bullet-1 \mathrm{mM} \mathrm{Mg}^{2+}, \square-\square$ Control.

\section{ATPase Activity at Various $p H$ 's}

The ATPase activity was found to vary with the change in $\mathrm{pH}$ as shown in Fig. 2. At both $50 \mathrm{mM}$ and $600 \mathrm{mM} \mathrm{KCl}$ and in the presence of
$\mathrm{Ca}^{2+}(5 \mathrm{~mm})$, there were found 2 peaks at $\mathrm{pH} 7.0$ and at near $\mathrm{pH} 8.5$, and a hollow at $\mathrm{pH} 8.0$. Such presence of 2 peaks was similar to the case with the Pecten myosin, ${ }^{3,4}$ though the $\mathrm{pH}$ values of each peak and hollow did not agree precisely between the both cases. However, the pattern of the curve with the squid myosin made much difference from that of the rabbit myosin where a peak is found at $\mathrm{pH} 6.4$ and the activity keeps rising beyond $\mathrm{pH} 8.0 .^{15)}$ The resuits in the presence of $\mathrm{Mg}^{2+}(1 \mathrm{mM})$ were not illustrated here, because there were but little variation with $\mathrm{pH}$ due to the low level of the activity.
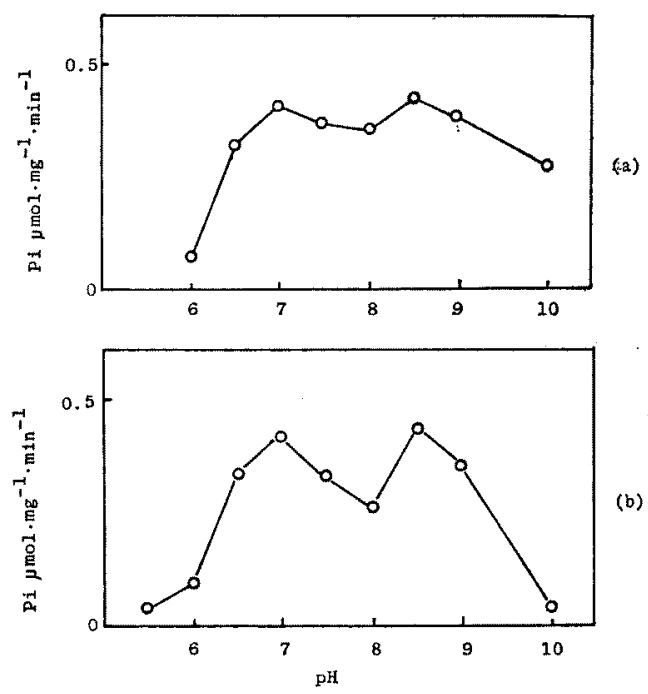

Fig. 2. ATPase activity of squid myosin at various pH's in the presence of $\mathrm{Ca}^{2+}$ added on $50 \mathrm{~mm}$ (a) and $600 \mathrm{~mm}$ (b) KCl. Conditions: Same to Fig. 1.

\section{Dependence of ATPase on Ionic Strength}

The ATPase activity in the presence of $\mathrm{Ca}^{2+}$ $(5 \mathrm{mM})$ varied in a function of $\mathrm{KCl}$ concentration as shown in Fig. 3. While the ATPase activity

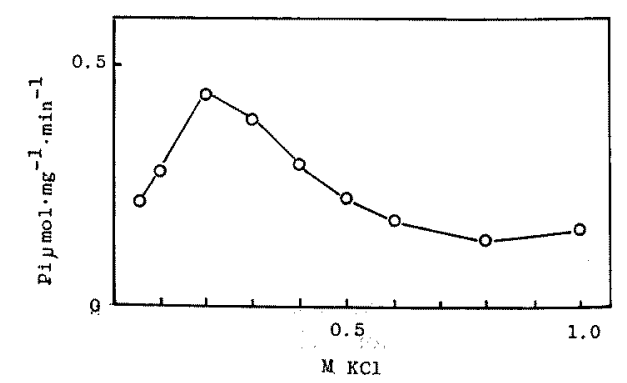

Fig. 3. ATPase activity of squid myosin at various concentrations of $\mathrm{KCl}$ with $\mathrm{Ca}^{2+}$ added Condi tions: Same to Fig. 1. 
of the skeletal myosins decreases linearly with increasing ionic strength, ${ }^{15}$ that of the squid myosin gave a curve with a peak at near $0.2 \mathrm{M}$ $\mathrm{KCl}$. The latter is identical with the case in the squid actomyosin ${ }^{121}$ and similar to the case in the Pecton myosin."

\section{Effect of $\mathrm{Ca}^{2+}$ and $\mathrm{Mg}^{2+}$ ions}

The ATPase activity at various concentrations of $\mathrm{Ca}^{2+}$ and $\mathrm{Mg}^{2+}$ ions was illustrated in Fig. 4 . At both the low and high ionic strengths, a maximum was found at $10^{-3}-10^{-2} \mathrm{M} \mathrm{Ca}^{2+}$, while a slight peak was found at $10^{-4} \mathbf{M ~ M g}^{2+}$ which was much less marked as compared with the case in the squid actomyosin. ${ }^{12)}$ Further detailed study at $10^{-4}-10^{-2} \mathrm{M} \mathrm{Ca}^{2+}$ and $\mathrm{Mg}^{2+}$ was carried out

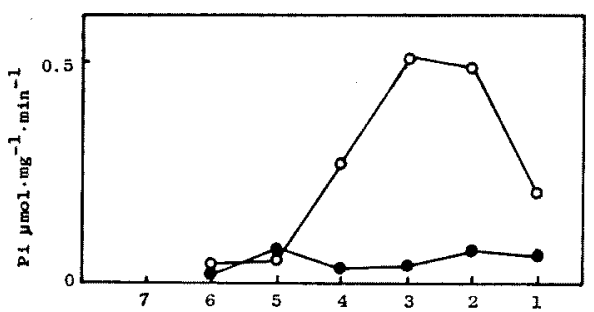

(a)

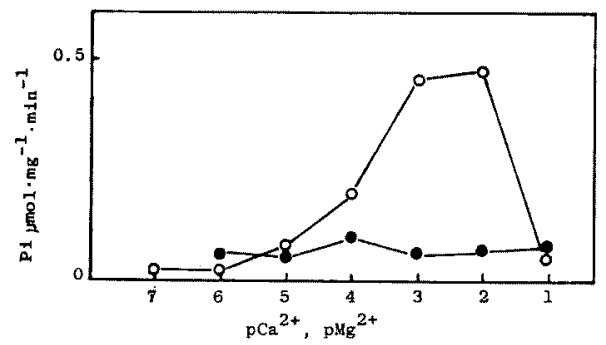

(b)

Fig. 4. ATPase activity of squid myosin at various concentrations of $\mathrm{Ca}^{2+}$ and $\mathrm{Mg}^{2+}$ added on $50 \mathrm{mM}$ (a) and $600 \mathrm{~mm}$ (b) $\mathrm{KCl}$. Conditions: Same to Fig. 1. $\bigcirc-\mathrm{O}, \mathrm{Ca}^{2+},-\mathrm{Mg}^{2+}$.

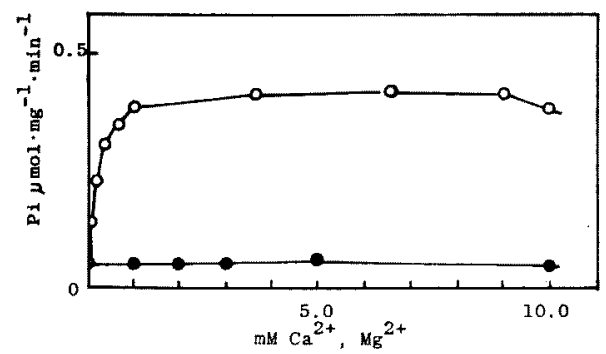

Fig. 5. ATPase activity of squid myosin at various concentrations between $0.1-9 \mathrm{mM}$ of $\mathrm{Ca}^{2+}$ and $\mathrm{Mg}^{2+}$ added on $600 \mathrm{mM} \mathrm{KCl} \mathrm{O}-\mathrm{O}, \mathrm{Ca}^{2+}$, - $\mathrm{Mg}^{2+}$. as shown in Fig. 5. Thus, the maximum value was attained between 1-9 $\mathrm{mm}$, while the curve with $\mathrm{Mg}^{2+}$ was flat.

\section{Effect of EDTA}

Effect of various amounts of EDTA on the ATPase activity was studied parallelly on the squid myosin as well as on the carp myosin for reference as shown in Fig. 6. While the activity of the carp myosin ATPase, like that of the rabbit myosin ATPase, ${ }^{171}$ was elevated with the raised EDTA concentration, that of the squid myosin was depressed with EDTA irrespective of the EDTA concentration. Such inactivation with EDTA, was found also in the squid actomyosin, ${ }^{12}$ and in the myosins of Pecten ${ }^{41}$ and Plasmodium. ${ }^{18)}$

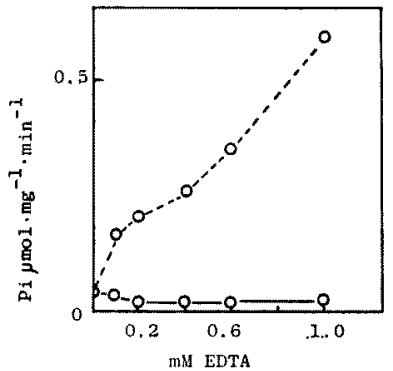

Fig. 6. ATPase activity of squid myosin at various concentrations of EDTA added on $600 \mathrm{mM} \mathrm{KCl}$. ○-O Squid, O---O Carp.

\section{Effect of PCMB}

The activity of $\mathrm{Ca}^{2+}$-ATPase and EDTAATPase of the squid myosin as a function of of PCMB ( $p$-chloromercuribenzoate) was studied resulting in Fig. 7 . Whereas the $\mathrm{Ca}^{2+}-\mathrm{ATPase}$ of the skeletal muscle myosins is activated with PCMB below $0.3-0.4 \mu \mathrm{M} / \mathrm{mg} \cdot$ protein and inactivated beyond that threshold condition, ${ }^{193}$ that of the squid myosin did not show any effect, either accelerative or decelerative, on the elevated activity of the $\mathrm{Ca}^{2+}$-ATPase and on the depressed activity of the EDTA-ATPase at any quantity of added PCMB. Such behavior of the squid myosin ATPase was also distinct from the $\mathrm{Ca}^{2+}$-ATPases of the myosins of smooth muscle ${ }^{201}$ and Plasmodium $^{18)}$ which show a linearly decreasing curve with the increasing PCMB. In the case of the EDTA-ATPase, the depressive effect of EDTA was not affected by PCMB added on.

\section{Discussion}

The present results on the ATPase activity of 


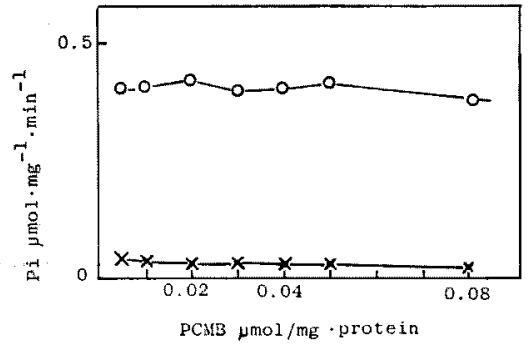

Fig. 7. Effect of PCMB on ATPase activity of squid myosin. Myosin was preincubated with PCMB for $10 \mathrm{~min}$ at $0^{\circ} \mathrm{C}$. ATPase activity was measured under the following conditions: Protein, $0.2 \mathrm{mg}$ / $\mathrm{ml} ; \mathrm{KCl}, 600 \mathrm{~mm}$, Tris-maleate buffer ( $\mathrm{pH} \mathrm{7.0)}$ ), $20 \mathrm{~mm} ; \mathrm{CaCl}_{2}, 5 \mathrm{~mm}$, or EDTA, $1 \mathrm{~mm}$; ATP, $1 \mathrm{~mm}$. O-O $\mathrm{Ca}_{2}{ }^{+}$ATPase, $\times-\times$EDTAATPase.

the squid myosin are summarized in Table 1 together with those of rabbit, ${ }^{16 !}$ carp, ${ }^{21}$ Pecten, ${ }^{41}$ lobster $^{81}$ and Plasmodium ${ }^{18)}$ for reference. As found in the Table, the squid myosin appears distinct from the myosins of other origins in some respects. The squid myosin is similar to the Pecten myosin with respect to the modes of dependence on $\mathrm{pH}$ and on ionic strength. However, myosin of another Molluscs, abolone, shows properties similar to those of the skeletal muscle myosins in the modes of dependence on $\mathrm{pH}$ and on ionic strength. Myosin of lobster, an Arthropod, belongs to the latter group. Thus, it seems difficult to define an ATPase profile to cover the characteristics of the molluscan myosins.

That the squid myosin ATPase is activated, though to little extent, with $\mathrm{Mg}^{2+}$ is a feature which is not found in any myosin of other origins so far studied and, thus, characteristic to the squid myosin.

Also, in the presence of EDTA added, the squid myosin ATPase was depressed in contrast to the case with the skeletal muscle myosin
ATPases which are activated. Such depression with EDTA might be related with that the squid myosin ATPase was activated by $\mathrm{Mg}^{2+}$ to some extent contrary to the skeletal myosin ATPases which are inactivated by $\mathrm{Mg}^{2+}$.

The effect of EDTA might involve the dissociation of a light chain from the squid myosin molecule as proposed by SzENT-GYöRGYI et al. ${ }^{22}$ ) Nevertheless, the recent data of the present authors* disproved such dissociation as well as the change in Ca-sensitivity of the squid myosin B by EDTA treatment. Thus, the present results of the EDTAdepressed ATPase should represent some property inherent to the squid myosin ATPase.

In the effect of PCMB on the ATPase activity, also, the squid myosin is different from the myosins of either skeletal muscle or smooth muscle. Though the squid myosin ATPase appears similar to that of Pecten with respect to the modes of dependence on $\mathrm{pH}$ and ionic strength, data on the effect of PCMB are lacking for the Pecten myosin.

The different sensitivity of the ATPases of the skeletal muscle myosins and the squid myosin to added PCMB might suggest a possible difference in the conformation involving $\mathrm{SH}$-groups near the active site. This view is compatible with the data that the content of unaccessible SH-groups is higher in the squid myosin than in the myosins of other origins. ${ }^{21}$

The present data altogether suggest that the squid myosin has ATPase profiles which are distinct from any myosins of vertebrate, invertebrate or nonmuscular origin so far studied, though it seems most similar to the Pecten myosin.

\section{References}

1) T. Tsuchiy A, N. Yamada, and J. J. Matsumoto: Bull. Japan. Soc. Sci. Fish., 44, 175-179 (1978)

Table 1. Properties of ATPase activity of squid, Pecten, lobster, carp, rabbit and Plasmodium

\begin{tabular}{|c|c|c|c|c|c|c|c|c|c|c|c|c|}
\hline \multirow{2}{*}{ Ionic strength } & \multicolumn{2}{|c|}{ Squid } & \multicolumn{2}{|c|}{ Pecten } & \multicolumn{2}{|c|}{ Lobster } & \multicolumn{2}{|c|}{ Carp } & \multicolumn{2}{|c|}{ Rabbit } & \multicolumn{2}{|c|}{ Plasmodium } \\
\hline & $\mathbf{L}$ & $\mathbf{H}$ & $\mathbf{L}$ & $\mathbf{H}$ & $\mathbf{L}$ & $\mathbf{H}$ & L & $\mathrm{H}$ & $\mathrm{L}$ & $\mathrm{H}$ & $\mathbf{L}$ & $\mathbf{H}$ \\
\hline \multicolumn{13}{|l|}{ Effect of } \\
\hline $\mathrm{Ca}^{2+}$ & + & + & + & + & & + & + & + & + & + & + & + \\
\hline $\mathrm{Mg}^{2+}$ & + & + & - & - & & - & - & - & - & - & - & - \\
\hline EDTA & - & - & - & - & & + & - & + & - & + & - & - \\
\hline \multicolumn{13}{|l|}{ Dependence on $\mathrm{pH}$} \\
\hline number of peaks & & & & 2 & & 2 & & 1 & & & & \\
\hline Dependence on $\mathrm{KCl}$ concn. & \multicolumn{4}{|c|}{ peak at $0.2 \mathrm{M} \mathrm{KCl}$} & \multicolumn{6}{|c|}{ decreasing with increasing $\mathrm{KCl}$} & & \\
\hline
\end{tabular}

* Unpublished data. 
2) T. Tsuchya, N. Yamada, and J. J. Matsumoto: Bull. Japan. Soc. Sci. Fish., 44, 181-184 (1978)

3) J. C. RÜEGG: Proc. Roy. Soc. B154, 209-223 (1961).

4) M. BÁrÁNY and K. BÁRÁnY: Biochem. Z., 345, 37-56 (1966).

5) G. W. De Villafranca and B. A. Friedman: Comp. Biochem. Physiol., 51B, 375-383 (1975).

6) K. Nishida: Bull. Japan. Soc. Sci. Fish., 43, 335-341 (1977).

7) S. WATABE and K. HASHumoto: Bull. Japan. Soc. Sci. Fish., 42, 1161-1167 (1976).

8) H. TomioKA, K. Yamaguch, K. Hashimoto, and F. MatsuUra：Bull. Japan. Soc. Sci. Fish., 41, 51-58 (1975).

9) N. Azuma, A. Asakura, and K. YaGI: J. Biochem., 77, 973-981 (1975).

10) M. Yamaguchi, T. Nakamura, H. OYa, and T. SeKINE: Biochem. Biophys. Acta, 317, 312-315 (1973).

11) G. W. De Villafranca and C. C. NaumanN: Comp. Biochem. Physiol., 12, 143-156 (1964).

12) N. Horie, T. Tsuchrya, and J. J. Matsumoto:
Bull. Japan. Soc. Sci. Fish., 41, 1039-1045 (1975).

13) C. H. Fiske and Y. Subbarow: J. Biol. Chem., 66, 375-400 (1925).

14) T. Tsuchiya and J. J. MAtsumoto: Bull. Japan. Soc. Sci. Fish., 41, 1319-1326 (1975).

15) D. Gilmour: Nature, 186, 295-298 (1960).

16) M. Bárány, E. GaetJens, K. BáránY, and E. KARP: Arch. Biochem. Biophys., 106, 280-293 (1964).

17) W. J. Bowen and T. D. KerwIN：J. Biol. Chem., 211, 237-247 (1954).

18) S. Hatano and J. OHNUMA: Biochem. Biophys. Acta, 205, 110-120 (1970).

19) W. W. Kielley and L. B. Bradley: J. Biol. Chem., 218, 653-659 (1956).

20) P. WACHSBERGER and G. KALDOR: Arch. Biochem. Biophys., 142, 127-137 (1971).

21) R. TAKASHI: Bull. Japan. Soc. Sci. Fish., 39, 197-205 (1973).

22) A. G. SZENT-GYoRgY, E. M. SZENTKIRALYI, and J. KENDRICK-JONES: J. Mol. Biol., 74, 179-208 (1973). 